(C) 2019. This manuscript version is made available under the CC-BY-NC-ND 4.0 license http://creativecommons.org/licenses/by-nc-nd/4.0/

\title{
Progress and perspectives on pillared clays applied in energetic
}

\section{and environmental remediation processes}

\author{
Antonio Gil ${ }^{1}$ and Miguel A. Vicente ${ }^{2}$ \\ ${ }^{1}$ INAMAT-Departamento de Ciencias, Edificio de los Acebos, Universidad Pública de \\ Navarra, Campus de Arrosadía, 31006-Pamplona, Spain. (e-mail: andoni@unavarra.es) \\ 2 GIR-QUESCAT, Departamento de Química Inorgánica, Facultad de Ciencias \\ Químicas, Universidad de Salamanca, 37008-Salamanca, Spain. (e-mail: \\ mavicente@usal.es)
}

\begin{abstract}
Pillared interlayered clays (PILCs) are materials that show a two-dimensional layered porous structure with properties that could be interesting alternatives to zeolites and other microporous solids. Some of the properties that make these materials interesting are: specific surface area, high exchange capacity, low permeability, swelling ability, relatively good heat-resistance stability, high acidic properties and relatively low price. PILCs have attracted intense research among several years in relation to the possible control of these properties and environmental applications. The current short work is devoted to the tendencies and new insights last five years of PILCs as adsorbents and heterogeneous catalysts. The work finishes considering the future application prospects.
\end{abstract}

Keywords: pillared clays, porous materials, catalysts, adsorbents. 


\section{Introduction}

The development of inorganic pillared interlayered clays (in short PILCs) has created new opportunities in the field of the synthesis and applications of porous clay-based solids. These materials are prepared by exchanging the charge-compensating cations present in the interlayer space of swelling clays with hydroxy-metal polycations. On calcining, the inserted polycations yield rigid, thermally stable oxide species, which prop apart the clay layers and prevent their collapse. Adjusting various parameters involved in the synthesis process can control all the properties related with the structure of these materials, giving them characteristics similar to those of zeolites [1,2]. PILCs show interesting applications such as adsorbents and heterogeneous catalysts mainly related to the removal of hazardous substances, such as heavy metals, dyes, biocides or pharmaceuticals, from aquatic systems.

\section{Pillared clay minerals as adsorbents}

Adsorption on porous materials with high specific surface area has been the predominant method of treatment of wastewaters owing to the low initial cost of the materials, simplicity of design, versatility, ease of operation, and insensitivity to toxic substances including hydrophobic organic contaminants, cationic/anionic dyes, heavy metal cations, oxyanions, etc. [3]. The porous structure of PILCs, in combination with the abundant $\mathrm{OH}$ groups, makes these type of materials efficient adsorbents for cationic and anionic contaminants [4] (see Figure 1), and various adsorption mechanisms have been proposed. However, adsorption implies the change of the pollutants from the liquid to the solid phase, but not their degradation. Other technologies used for this purpose include ionexchange, chemical precipitation, reverse osmosis, membrane filtration, among others. These methods are in general more expensive that adsorption. The liquid phase adsorption 
is affected by many factors such as the $\mathrm{pH}$, the type of adsorbent, the solubility of the adsorbate in the solvent, the temperature, the concentration of the adsorbate, the contact time between the adsorbent and adsorbate, etc. These aspects are usually modified in research works to study the efficiency of the adsorbents against the contaminants.

The release of heavy metals into the environment is a potential threat to water and soil quality as well as to plant, animal and human health. Heavy metals can be bioaccumulated through food chain transfers and unlike organic pollutants are not amenable to biological degradation. Heavy metals can be introduced into and accumulated in soils through agricultural application of sewage sludge, fertilizers, and/or through land disposal of contaminated municipal and industrial wastes. The removal and separation of heavy metals from wastewaters is an attractive field where pillared clays can be used as adsorbent materials. The application of PILCs to environmental pollution control in terms of heavy metals removal from aqueous media has received scant attention in the last years [5-10]. In general, four different mechanisms have been proposed for the uptake of heavy metal cations on PILCs: cation-exchange, chemical adsorption, structural incorporation and surface precipitation, but commonly cation-exchange has been recognized as removal mechanism. A Romanian natural calcium bentonite was used by Georgescu et al. [11] to prepare a Cr-pillared clay as adsorbent of lead ions from aqueous solutions. The results found were explained considering two aspects: the chemical binding between lead ions and surface hydroxyl groups and the electrostatic binding between lead ions and the permanent negatively charged sites of montmorillonite. The synthesis of adsorbents based on pillared clays for immobilization of arsenic species from gold mine wastewater under alkaline condition has been reported by Barakan and Aghazadeh [12], who indicated that there was a limited approach in alkaline mine wastewater because of the negative surface charge of most adsorbents. In this regard, the synthesis of AlFe-PILCs was proposed, 
obtaining a material with a specific surface area of $174 \mathrm{~m}^{2} / \mathrm{g}$ after calcination at $500{ }^{\circ} \mathrm{C}$ for $2 \mathrm{~h}$. The $\mathrm{pH}$ was a critical parameter for adsorption processes and arsenate was the predominant species in the alkaline wastewater. Mnasri-Ghnimi and Frini-Srasra [13] suggested the application of single (Al- and Zr-PILCs) and mixed (AlZr-, CeAl-, CeZrand CeAlZr-PILCs) pillared clays for the removal of $\mathrm{Cd}(\mathrm{II}), \mathrm{Co}(\mathrm{II})$ and $\mathrm{Cu}(\mathrm{II})$ under several conditions. The experimental results indicated that the presence of $\mathrm{Ce}$ on the PILCs provided better properties for the removal of the metal cations.

The large use of antibiotics is causing an increase of drug levels in the environment due to the high percentage of unmetabolized active ingredients excreted by the living organisms (30-90\%). As a result, bacteria are generating resistance to them; for this reason, a large number of researchers have carried out studies on the adsorption of antibiotics, and organic contaminants in general, from water by using several pillared clays [14-21]. Four types of PILCs have been evaluated by Roca Jalil et al. [22] for the removal of ciprofloxacin $\left(\mathrm{C}_{17} \mathrm{H}_{18} \mathrm{FN}_{3} \mathrm{O}_{3}\right)$ from aqueous solutions. The highest ciprofloxacin adsorption capacities were found for $\mathrm{Si}$ - and Fe-PILC, related to the porous structure of the materials. Ti-PILCs have been tested by González et al. [23] as adsorbents of methylene blue $\left(\mathrm{C}_{16} \mathrm{H}_{18} \mathrm{ClN}_{3} \mathrm{~S}\right)$ and trimethoprim $\left(\mathrm{C}_{14} \mathrm{H}_{18} \mathrm{~N}_{4} \mathrm{O}_{3}\right)$. Doping cations were incorporated into Ti-pillared montmorillonite, evaluating the changes in the structural, textural and surface properties, and their effects in the adsorption capacity of the materials under kinetics and equilibrium conditions.

The presence of nutrients as phosphate without control can lead to serious water eutrophication problems. The removal of phosphate by adsorption has been proposed by Xia et al. [24] using a $\mathrm{Mg} / \mathrm{Al}$-pillared montmorillonite loaded with $\mathrm{La}(\mathrm{OH})_{3}$. The adsorbents were prepared from various $\mathrm{Mg} / \mathrm{Al}$ molar ratios and investigated in batch adsorption experiments. The results obtained considering several parameters showed that 
adsorption was spontaneous and endothermic in nature. The proposed adsorption mechanism involved ion exchange with intercalated anions and surface coordination with the loaded hydroxides. The presence of other anions as $\mathrm{NO}_{2}^{-}, \mathrm{NO}_{3}{ }^{-}, \mathrm{Cl}^{-}$and $\mathrm{SO}_{4}{ }^{2-}$ decreased the removal of phosphate.

\section{Pillared clay minerals as heterogeneous catalysts}

The use of PILCs as catalyst and as support for active catalytic phases is one of the most studied topics for these materials, particularly in environment related reactions. The acidity developed by PILCs is interesting for reactions as alkylation, dehydrogenation, hydrocracking and isomerization [25]. In the case of metal supported catalysts, the selective reduction of $\mathrm{NO}_{\mathrm{x}}$ [26,27], the complete oxidation of VOCs [28-33] and the wet hydrogen peroxide catalytic oxidation of wastewater [34,35] are the most interesting reactions where PILCs have been applied (see Figure 2).

A new strategy for the synthesis of Al-PILCs have been recently reported considering the intercalation of a montmorillonite with $\mathrm{Keggin}^{-\mathrm{Al}_{30}}$ polycations $\left(\mathrm{Al}_{2} \mathrm{O}_{8} \mathrm{Al}_{28}(\mathrm{OH})_{56}\left(\mathrm{H}_{2} \mathrm{O}\right)_{24}{ }^{18+}\right)$ (see Figure 3) [36]. Zhu et al. [37] have developed a method to prepare $\mathrm{Al}_{30}$-PILCs from the intercalation of a montmorillonite and a base-hydrolyzed solution of $\mathrm{Al}(\mathrm{III})$ chloride, where the formation of the Keggin- $\mathrm{Al}_{30}$ polycation is confirmed by liquid ${ }^{27} \mathrm{Al} \mathrm{NMR}$ analysis. The specific surface area of the new material increase from $259 \mathrm{~m}^{2} / \mathrm{g}\left(\mathrm{Al}_{13}\right.$-PILC) to $311 \mathrm{~m}^{2} / \mathrm{g}$ ( $\mathrm{Al}_{30}$-PILC). The oxidation of toluene has been used to study the catalytic behavior of these materials [38], finding that the presence of the new polycations into the interlayer of the montmorillonite can lead more Brönsted acid sites and stronger acid sites than Keggin- $\mathrm{Al}_{13}$ polycations because of the large positive charge in each $\mathrm{Keggin}-\mathrm{Al}_{30}$ unit. As result, the toluene conversion was higher at lower temperature using this new catalyst. 
Titanium dioxide is the most widely used catalyst for the photodegradation of pollutants because of its photoelectric properties, low cost, resistance to corrosion, non-toxicity and chemical stability in a wide $\mathrm{pH}$ range [39]. Clay minerals pillared with titanium can show greater photoactivity than $\mathrm{TiO}_{2}$ particles and thus these materials have been widely used for photocatalytic removal of contaminants [40]. Montmorillonite- $\mathrm{TiO}_{2}$ nanocomposites were prepared by González et al. [41] using two methods (ultrasonic and stirring) and titanium(IV) isopropoxide as precursor. These nanocomposites were considered as active catalysts for the photodegradation of 1,2,4-trichlorobenzene $\left(\mathrm{C}_{6} \mathrm{H}_{3} \mathrm{Cl}_{3}, \mathrm{TCB}\right)$. The degradation of this molecule was very fast, and began by the removal of the chlorine atoms, also involving the dimerization of the benzene ring, and the bonding to the ring of fragments previously removed from other molecules. González et al. [42,43] also reported the photodegradation of the antibiotic trimethoprim under several conditions, as in the dark or under UV light, with or without catalyst, using a Ti pillared montmorillonite doped with $\mathrm{Cr}^{3+}$ or $\mathrm{Fe}^{3+}$. The solid doped with $\mathrm{Cr}^{3+}$ exhibited the best behavior, with photodegradation close to $76 \%$ after $180 \mathrm{~min}$ of reaction. The degradation by-products were analyzed by mass spectrometry suggesting that the molecule broke in two halves, related to the two existing rings: trimethoxybenzene and diaminopyridine halves (see Figure 4). The breakage of small fragments mainly from the trimethoxybenzene half of the molecule, the reaction of these fragments with the methoxy groups of other molecules leading to species larger than the initial molecule, and the subsequent breakage to new fragments was also possible.

Although the degradation of dyes is usually undertaken by means of oxidation reactions, a reductive approach has also been reported, using $\mathrm{NaBH}_{4}$ as reducing agent for methylene blue degradation by Pd-supported $\mathrm{Cu}$-doped Ti-pillared montmorillonite [44]. 
The removal of methylene blue was rapid and almost complete at room temperature, in presence of light, after about $20 \mathrm{~min}$ in the presence of the catalyst.

$\mathrm{Al} / \mathrm{Fe}-\mathrm{PILCs}$ have exhibited high performance activating the catalytic wet peroxidation (CWPO) in heterogeneous phase, and have therefore been used in the degradation of several organic compounds present in water, including emerging pollutants, phenolic compounds, natural organic matter and various toxic and bio-refractory azo-dyes [34]. A new methodological approach to obtain $10 \mathrm{~kg}$ scaled-up preparation of $\mathrm{Al} / \mathrm{Fe}-\mathrm{PILC}$ CWPO catalysts applied to the oxidation of phenol has been reported by Muñoz et al. [45]. This procedure opens the pilot and industrial scale approaches of PILC catalysts. Ramírez et al. [46] optimized CWPO phenol oxidation by statistical tools of experimental design and multi-response surface methodology in a CSTR reactor under mild conditions. Maximal TOC and phenol removals of 31 and 65\%, respectively, under atmospheric pressure, room temperature and neutral $\mathrm{pH}$ were reported. Several natural pillared clays $(\mathrm{Al} / \mathrm{Cu}-$ and $\mathrm{Al} / \mathrm{Fe}-\mathrm{PILCs})$ have been used as heterogeneous photocatalysts for the $\mathrm{H}_{2} \mathrm{O}_{2}$ assisted treatment of a real winery wastewater, characterized by the presence of polyphenolic compounds [47], finding higher catalytic performances for $\mathrm{Al} / \mathrm{Cu}$ - than for Al/Fe-PILC. A $\mathrm{Cu} / \mathrm{Fe}-\mathrm{PILC}$ catalyst efficient for the mineralization of paracetamol through a photo-Fenton process has been presented by Hurtado et al. [48]. The oxidation of tartrazine, $\mathrm{C}_{16} \mathrm{H}_{9} \mathrm{~N}_{4} \mathrm{Na}_{3} \mathrm{O}_{9} \mathrm{~S}_{2}$, a model dye pollutant, in the presence of oxone and using a Co/Al-PILC as catalyst, has been reported by Markovic et al. [49].

The need to reduce greenhouse gas emissions into the atmosphere makes that the capture, storage and utilization of $\mathrm{CO}_{2}$ to produce valuable chemicals has gained importance in the last years. In this respect, value-added products synthesis by the hydrogenation of $\mathrm{CO}_{2}$ reaction has attracted the attention of Marcos et al. [50], using $\mathrm{CuFe}$ and $\mathrm{CuCo}$ supported on Al/V-PILC. A linear relationship between the $\mathrm{CO}_{2}$ conversion and the metal 
surface area of the $\mathrm{Cu}$-based catalysts was found. Methane reforming with $\mathrm{CO}_{2}$ is other possible alternative to produce syngas and also to reduce the emissions of $\mathrm{CO}_{2}$, as done by Mofrad et al. over Ni/Al-PILC [51]. The evaluation of the $\mathrm{CO}_{2}$ adsorption capacity is a previous step in this type of applications [52].

\section{Future applications and conclusions}

Despite of the achievements presented in the work, there are still many interesting areas to be explored for applications of PILCs based materials. The porous structure of these materials can be designed and controlled, so they can be adapted to the desired applications. The intercalation of the layered clays can be oriented towards new structures and towards new sources of polycations, such as the recovery of industrial metal wastes. Once PILCs have been applied as adsorbents, these materials can be reused as new adsorbents or catalysts, closing the cycle of new concepts in Circular Economy. This will give the intercalation and pillaring of clay minerals a new important role in materials science, as they have had so far.

\section{Conflict of interest statement}

Nothing declared.

\section{Acknowledgments}

The authors gratefully acknowledge funding from the Spanish Ministry of Economy, Industry and Competitiveness (AEI/MINECO), and the European Regional Development Fund (ERDF) through project MAT2016-78863-C2-2-R. AG also thanks Santander Bank for funding through the Research Intensification Program. 
References and recommended reading

Papers of particular interest, published within the period of review, have been highlighted as:

*of special interest

**of outstanding interest

1. Gil A, Korili SA, Vicente MA: Recent advances in the control and characterization of the porous structure of pillared clay catalysts. Catal Rev-Sci Eng 2008, 50:153-221. https://doi.org/10.1080/01614940802019383.

2. Gil A, Vicente MA, Korili, SA: Effect of the Si/Al ratio on the structure and surface properties of silica-alumina-pillared clays. J Catal 2005, 229:119-126. https://doi.org/10.1016/j.jcat.2004.10.013.

3. Zhu R, Chen Q, Zhou Q, Xi Y, Zhu J, He H: Adsorbents based on montmorillonite for contaminant removal from water: A review. Appl Clay Sci 2016, 123:239-258. http://dx.doi.org/10.1016/j.clay.2015.12.024.

4. Gil A, Assis FCC, Albeniz S, Korili SA: Removal of dyes from wastewaters by adsorption on pillared clays. Chem Eng $J$ 2011, 168:1032-1040. https://doi.org/10.1016/j.cej.2011.01.078.

5. Jobstmann H, Sing B: Cadmium sorption by hydroxyl-aluminium interlayered montmorillonite. Water Air Soil Pollut 2001, 131: 203-215. https://doi.org/10.1023/A:1011928829059.

6. Manohar DM, Noeline BF, Anirudhan TS: Adsorption performance of Al-pillared bentonite clay for the removal of cobalt(II) from aqueous phase. Appl Clay Sci 2006, 31:194-206. https://doi.org/10.1016/j.clay.2005.08.008. 
7. Manohar DM, Noelite BF, Anirudhan TS: Removal of Vanadium (IV) from aqueous solutions by adsorption process with aluminum-pillared bentonite. Ind Eng Chem Res 2005, 44:6676-6684. https://doi.org/10.1021/ie0490841.

8. Liang-Guo Y, Xiao-Quan S, Bei W, Gary O: Adsorption of cadmium onto Al13pillared acid-activated montmorillonite. J Hazard Mater 2008, 156:499-508. https://doi.org/10.1016/j.jhazmat.2007.12.045.

9. Guerra DL, Airoldi C, Lemos VP, Angélica RS: Adsorptive, thermodynamic and kinetic performances of $\mathrm{Al} / \mathrm{Ti}$ and $\mathrm{Al} / \mathrm{Zr}$-pillared clays from the Brazilian Amazon region for zinc cation removal. J Hazard Mater 2008, 155:230-242. https://doi.org/ 10.1016/j.jhazmat.2007.11.054.

10. Mishra T, Mahato DK: A comparative study on enhanced arsenic (V) and arsenic (III) removal by iron oxide and manganese oxide pillared clays from ground water. $J$ Environ Chem Eng 2016, 4:1224-1230. https://doi.org/10.1016/j.jece.2016.01.022.

11. Georgescu A-M, Nardou F, Zichil V, Nistor ID: Adsorption of lead (II) ions from aqueous solutions onto Cr-pillared clays. Appl Clay Sci 2018, 152:44-50. https://doi.org/10.1016/j.clay.2017.10.031.

12. Barakan Sh, Aghazadeh V: Structural modification of nano bentonite by aluminum, iron pillarization and 3D growth of silica mesoporous framework for arsenic removal from gold mine wastewater. J Hazard Mater 2019, 378:120779. https//doi.org/10.1016/j.jhazmat.2019.120779.

**The authors indicated that the modification of natural bentonite by pillarization created a new group of porous materials for immobilization of arsenic species from gold mine wastewater. In this way, Al-, AlFe-PILCs and heterostructures were synthesized as 
porous materials and applied to the removal of arsenic species at $\mathrm{pH}=10 . \mathrm{pH}$ was the critical parameter for this application.

13. Mnasri-Ghnimi S, Frini-Srasra N: Removal of heavy metals from aqueous solutions by adsorption using single and mixed pillared clays. Appl Clay Sci 2019, 179:105151. https://doi.org/10.1016/j.clay.2019.105151.

14. Bouras $\mathrm{O}$, Bollinger JC, Baudu M, Khalaf $\mathrm{H}$ : Adsorption of diuron and its degradation products from aqueous solution by surfactant-modified pillared clays. Appl Clay Sci 2007, 37:240-250. https://doi.org/10.1016/j.clay.2007.01.009.

15. Molu ZB, Yurdakoc K: Preparation and characterization of aluminium pillared K10 and KSF for adsorption of trimethoprim. Microporous Mesoporous Mater 2010, 127:50-60. https://doi.org/10.1016/j.micromeso.2009.06.027.

16. Hou MF, Ma C-X, Zhang W-D, Tang X-Y, Fan Y-N, Wan H-F: Removal of rhodamine B using iron-pillared bentonite. J Hazard Mater 2011, 186:1118-1123. https://doi.org/10.1016/j.jhazmat.2010.11.110.

17. Roca Jalil ME, Vieira RS, Azevedo D, Baschini M, Sapag K: Improvement in the adsorption of thiabendazole by using aluminum pillared clays. Appl Clay Sci 2013, 71:55-63. https://doi.org/10.1016/j.clay.2012.11.005.

18. Roca Jalil ME, Baschini M, Rodríguez-Castellón E, Infantes-Molina A, Sapag K: Effect of the $\mathrm{Al} /$ clay ratio on the thiabendazole removal by aluminum pillared clays. Appl Clay Sci 2014, 87:245-263. https://doi.org/ 10.1016/j.clay.2013.11.014.

19. Liu YN, Dong C, Wei H, Yuan W, Li K: Adsorption of levofloxacin onto an ironpillared montmorillonite (clay mineral): Kinetics, equilibrium and mechanism. Appl Clay Sci 2015, 118:301-307. https://doi.org/10.1016/j.clay.2015.10.010.

20. Khelifi S, Ayari F, Choukchou-Braham A, Chehimi DBH: The remarkable effect of Al-Fe pillaring on the adsorption and catalytic activity of natural Tunisian 
bentonite in the degradation of azo dye. J Porous Mater 2018, 25:885-896. https://doi.org/10.1007/s10934-017-0500-4.

21. Chauhan M, Saini VK, Suthar S: Removal of pharmaceuticals and personal care products (PPCPs) from water by adsorption on aluminum pillared clay. $J$ Porous Mater 2019 (in press). https://doi.org/10.1007/s10934-019-00817-8.

**The adsorptive removal properties of an Al-PILC $\left(258 \mathrm{~m}^{2} / \mathrm{g}\right)$ was evaluated on two selected pharmaceuticals and personal care products (PPCPs): amoxicillin (AMOX) and imipramine (IMP). The results of the removal of these pollutants were compared as a function of contact time (0-180 min), solution $\mathrm{pH}$ (2-12), initial concentration (0-100 $\left.\mathrm{mg} / \mathrm{dm}^{3}\right)$, and temperature (298-318 K). The results were also compared to natural clay, finding that the acidic sites incorporated into the clay enhanced its adsorption properties. The maximum adsorption capacity on Al-PILC followed the order IMP > AMOX.

22. Roca Jalil, ME, Baschini M, Sapag K: Removal of ciprofloxacin from aqueous solutions using pillared clays. Materials 2017, 10:1345. https://doi.org/10.3390/ma10121345.

*The removal of ciprofloxacin from aqueous solutions by adsorption on various PILCs under basic $\mathrm{pH}$ conditions $(\mathrm{pH}=10)$ was presented. Four PILCs were synthesized and evaluated as adsorbents. The authors suggested that the adsorption mechanism involved inner-sphere complexes formation and van der Waals interactions between $\mathrm{CPX}^{-}$and the surface adsorption sites.

23. González B, Trujillano R, Vicente MA, Rives V, de Faria EH, Ciuffi KJ, Korili SA, Gil A: Doped Ti-pillared clays as effective adsorbents-Application to methylene blue and trimethoprim removal. Environ Chem 2017, 14: 267-278. https://doi.org/10.1071/EN16192_AC. 
24. Xia M, Gao R, Wang Y, Wang S, Yun Y, Dou J: Synthesis and phosphate adsorption behavior of $\mathrm{Mg} / \mathrm{Al}$-pillared montmorillonite loaded with $\mathrm{La}(\mathrm{OH})_{3}$. Environ Technol 2019 (in press). https://doi.org/10.1080/09593330.2019.1675775.

25. Timofeeva MN, Panchenko VN, Matrosova MM, Andreev AS, Tsybulya SV, Gil A, Vicente MA: Factors affecting the catalytic performance of $\mathrm{Zr}$,Al-pillared clays in the synthesis of propylene glycol methyl ether. Ind Eng Chem Res 2014, 53:13565-13574. https://doi.org/10.1021/ie501048a.

26. Cheng J, Song Y, Ye Q, Cheng S, Kang T, Dai H: A mechanistic investigation on the selective catalytic reduction of NO with ammonia over the V-Ce/Ti-PILC $\begin{array}{llll}\text { catalysts. } & \text { Mol } & \text { Catal } & \text { 445:111-123. }\end{array}$ https://doi.org/10.1016/j.mcat.2017.11.019.

27. Cheng J, Ye Q, Zheng C, Cheng S, Kang T, Dai H: Effect of ceria loading on Zrpillared clay catalysts for selective catalytic reduction of NO with $\mathrm{NH}_{3}$. $\mathrm{New} \mathrm{J}$ Chem 2019, 43:10850-10858.

* $\mathrm{CeO}_{2} / \mathrm{Zr}$-PILC catalysts were prepared using $\mathrm{Zr}$-pillaring and impregnation methods. The catalyst with 5 wt. $\%$ of $\mathrm{CeO}_{2}$ showed $93 \%$ NO conversion at $400{ }^{\circ} \mathrm{C}$. The interesting catalytic properties of the solids were related to the $\mathrm{Ce}^{3+} / \mathrm{Ce}^{4+}$ ratio and the acidity properties on the surface of the catalyst evaluated from $\mathrm{NH}_{3}-\mathrm{TPD}$.

28. Aznárez A, Gil A, Korili SA: Performance of palladium and platinum supported on alumina pillared clays in the catalytic combustion of propene. $R S C A d v 2015$, 5:82296-82309. https://doi.org/10.1039/C5RA15675K.

29. Aznárez A, Delaigle R, Eloy P, Gaigneaux EM, Korili SA, Gil A: Catalysts based on pillared clays for the oxidation of chlorobenzene. Catal Today 2015, 246:1527. http://dx.doi.org/10.1016/j.cattod.2014.07.024. 
30. Zuo S, Yang P, Wang X: Efficient and environmentally friendly synthesis of AlFe-PILC-supported MnCe catalysts for benzene combustion. ACS Omega 2017, 2: 5179-5186. https://doi.org/10.1021/acsomega.7b00592.

31. Cheng Z, Chen Z, Li J, Zuo S, Yang P: Mesoporous silica-pillared clays supported nanosized $\mathrm{Co}_{3} \mathrm{O}_{4}-\mathrm{CeO}_{2}$ for catalytic combustion of toluene. Appl Surf Sci 2018, 459:32-39. https://doi.org/10.1016/j.apsusc.2018.07.203.

32. Feng B, Wei Y, Qiu Y, Zuo S, Ye N: Ce-modified AlZr pillared clays supportedtransition metals for catalytic combustion of chlorobenzene. J Rare Earths 2018, 36:1169-1174.

33. Rakitskaya TL, Dzhyga GM, Kiose TA, Oleksenko LP, Volkova VY: Pd(II), Cu(II), and pillared clay based nanocatalysts for low-temperature CO oxidation. $S N$ Appl Sci 2019, 1:291. https://doi.org/10.1007/s42452-019-0314x.

34. Galeano AL, Vicente MA, Gil A: Catalytic degradation of organic pollutants in aqueous streams by mixed Al/M-pillared clays $(\mathbf{M}=\mathbf{F e}, \mathbf{C u}, \mathbf{M n})$. Catal Rev Sci Eng 2014, 56:239-287. https://doi.org/10.1080/01614940.2014.904182.

35. Khankhasaeva STs, Dambueva DV, Dashinamzhilova ETs, Gil A, Vicente MA, Timofeeva MN: Fenton degradation of sulfanilamide in the presence of Al,Fepillared clay: Catalytic behavior and identification of the intermediates. $J$ Hazard Mater 2015, 293:21-29. http://dx.doi.org/10.1016/j.jhazmat.2015.03.038.

36. Allouche L, Gérardin C, Loiseau Th, Férey G, Taulelle F: Al30: A giant aluminum polycation. Angew Chem Int $E d$ 2000, 39:511-514. https://doi.org/ 10.1002/(SICI)1521-3773(20000204)39:3<511::AID-ANIE511>3.0.CO;2-N

37. Zhu J, Wen K, Zhang P, Wang Y, Ma L, Xi Y, Zhu R, Liu H, He H: Keggin-Also pillared montmorillonite. Micropor Mesopor Mater 2017, 242:256-263. http://dx.doi.org/10.1016/j.micromeso.2017.01.039. 
**A new method was developed to prepare $\mathrm{Al}_{30}$-PILCs from a base-hydrolyzed solution of Al(III) chloride. The procedure may open new opportunities in the application of PILCs as heterogeneous catalysts and porous adsorbents.

38. Wen K, Zhu J, Chen H, Ma L, Liu H, Zhu R, Xi Y, He H: Arrangement models of Keggin-Al $\mathrm{Al}_{30}$ and Kegging-Al $\mathrm{A}_{13}$ in the interlayer of montmorillonite and the impacts of pillaring on surface acidity: A comparative study on catalytic $\begin{array}{lllll}\text { oxidation } & \text { of } & \text { toluene. }\end{array}$ https://doi.org/10.1021/acs.langmuir.8b03447.

39. Deng F, Zhao X, Pei X, Luo X, Li W, Au C: Sol-hydrothermal synthesis of inorganic framework molecularly imprinted $\mathrm{TiO}_{2}$ nanoparticle and its enhanced photocatalytic activity for degradation of target pollutant. $S c i A d v$ Mater 2016, 8:1079-1085. https://doi.org/ 10.1166/sam.2016.2695.

40. Szczepanik B: Photocatalytic degradation of organic contaminants over clayTiO2 $_{2}$ nanocomposites: a review. Appl Clay Sci 2017, 141:227-239. https://doi.org/10.1016/j.clay.2017.02.029.

41. González B, Muñoz B, Vicente MA, Trujillano R, Rives V, Gil A, Korili S: Photodegradation of 1,2,4-trichlorobenzene on montmorillonite- $\mathrm{TiO}_{2}$ $\begin{array}{lll}\text { nanocomposites. } & \text { ChemEngineering } & \mathbf{2} 22 \text {. }\end{array}$ https://doi.org/10.3390/chemengineering2020022.

42. González B, Trujillano R, Vicente MA, Rives V, Korili SA, Gil A: Photocatalytic degradation of trimethoprim on doped Ti-pillared montmorillonite. Appl Clay Sci 2019, 167:43-49. https://doi.org/10.1016/j.clay.2018.10.006.

**Ti-PILCs doped with $\mathrm{Cr}^{3+}$ or $\mathrm{Fe}^{3+}$ were evaluated as catalysts for the photodegradation of trimethoprim under dark or in UV radiation, with or without catalyst. The degradation mechanism and by-products generated were analyzed by mass spectroscopy. 
43. González-Rodríguez B, Trujillano R, Rives V, Vicente MA, Gil A, Korili SA: Structural, textural and acidic properties of $\mathrm{Cu}$-, $\mathrm{Fe}$ - and $\mathrm{Cr}$-doped Ti-pillared montmorillonites. Appl Clay Sci 2015, 118:124-130. https://dx.doi.org/10.1016/j.clay.2015.09.0010.

44. Joseph A, Vellayan K, González B, Vicente MA, Gil A: Effective degradation of methylene blue in aqueous solution using Pd-supported $\mathrm{Cu}$-doped Ti-pillared montmorillonite catalyst. Appl Clay Sci 2019, 168:7-10. https://doi.org/10.1016/j.clay.2018.10.009.

45. Muñoz H-J, Vallejo C, Blanco C, Gil A, Vicente MA, Ramírez J-H, Galeano LA: 10 kg scaled-up preparation of Al/Fe-pillared clay CWPO catalysts from concentrated precursors. Green Chem 2018, 20:5196-5208. https://doi.org/10.1039/c8gc02445f.

**A novel approach to prepare A1/Fe-PILCs from highly concentrated intercalating metal solutions (up to around 100 times higher the standard) was reported. The materials were applied in the CWPO of phenol in aqueous medium at mild reaction temperature $\left(25^{\circ} \mathrm{C}\right)$ and pressure $(76 \mathrm{kPa})$. This new approach opens the application of PILCs at the pilot and industrial scales, mainly within the scope of the energetic and environmental catalysis.

46. Ramírez JH, Galeano LA, Pinchao G, Bedoya RA, Hidalgo A: Optimized CWPO phenol oxidation in CSTR reactor catalyzed by Al/Fe-PILC from concentrated precursors at circumneutral pH. J Environ Chem Eng 2018, 6:2429-2441. https://doi.org/10.1016/j.jece.2018.02.024.

*The CWPO of phenol catalyzed by an Al/Fe-PILC catalyst was optimized in a CSTR reactor. Various factors were considered as: maximization of pollutant's degradation and mineralization, minimization of $\mathrm{H}_{2} \mathrm{O}_{2}$ consumption, among others. The authors found optimal multi-response performance ( $65 \%$ of phenol degradation and $31 \%$ of TOC 
removal, $650 \mathrm{mg} \mathrm{H}_{2} \mathrm{O}_{2} / \mathrm{dm}^{3}$ in output stream) under stationary state with residence time of $135 \mathrm{~min}$, room temperature and neutral $\mathrm{pH}$ using $1.77 \mathrm{~g} / \mathrm{dm}^{3}$ of the clay catalyst.

47. Guimaraes V, Teixeira AR, Lucas MS, Silva AMT, Peres JA: Pillared interlayered natural clays as heterogeneous photocatalysts for $\mathrm{H}_{2} \mathrm{O}_{2}$-assisted treatment of a winery wastewater. Sep Purif Technol 2019, 228:115768. https://doi.org/10.1016/j.seppur.2019.115768.

**Interesting results were found in the treatment of a winery wastewater by using AlFeand $\mathrm{AlCu}$-PILCs as heterogeneous photocatalysts. The best catalytic performances were obtained for AlCu-PILC, related to the high specific surface area and porosity in comparison to AlFe-PILC.

48. Hurtado L, Romero R, Mendoza A, Brewer Sh, Donkor K, Gómez-Espinosa RM, Natividad R; Paracetamol mineralization by Photo Fenton process catalyzed by a $\mathrm{Cu} / \mathrm{Fe}$-PILC under circumneutral $\mathbf{p H}$ conditions. J. Photochem Photobiol. A 2019; 373:162-170. https://doi.org/10.1016/j.photochem.2019.01.012.

49. Markovic M, Marinovic S, Mudrinic T, Ajdukovic M, Jovic-Jovicic N, Mojovic, Z., Orlic Z, Mulutinovic-Nikolic A, Bankovic P: Co(II) impregnated Al(III)-pillared montmorillonite-Synthesis, characterization and catalytic properties in Oxone activation for dye degradation. Appl Clay Sci 2019, 182:105276. https://doi.org/10.1016/j.clay.2019.105276.

50. Marcos FCF, Assaf JM, Assaf EM: CuFe and CuCo supported on pillared clay as catalysts for $\mathrm{CO}_{2}$ hydrogenation into value-added products in one-step. $\mathrm{Mol}$ Catal 2018, 458:297-306. https://doi.org/10.1016/j.mcat.2017.12.025.

*In this paper, the authors presented the synthesis of value-added products, methanol and DME, by the one-step $\mathrm{CO}_{2}$ hydrogenation reaction. Three catalysts were studied: $\mathrm{Cu} / \mathrm{Al}-$ PILC, CuFe/Al-PILC and CuCo/Al-PILC. The catalytic conditions were: $250-300{ }^{\circ} \mathrm{C}$ and 
40 bar, previous reduction of the catalysts for $1 \mathrm{~h}$ at $300^{\circ} \mathrm{C}, \mathrm{H}_{2}: \mathrm{CO}_{2}$ molar ratio of $3: 1$ and GHSV $=20.000 \mathrm{dm}^{3} / \mathrm{kg}_{\mathrm{cat}} \cdot \mathrm{h}$.

51. Mofrad BD, Rezaei M, Hayati-Ashtiani M: Preparation and characterization of Ni catalysts supported on pillared nanoporous bentonite powders for dry reforming reaction. Int $J$ Hydrogen Energy 2019, 44:27429-27444. https://doi.org/10.1016/j.ijhydene.2019.08.194.

52. Garcés-Polo SI, Villarroel-Rocha J, Sapag K, Korili SA, Gil A: A comparative study of $\mathrm{CO}_{2}$ diffusion from adsorption kinetic measurements on microporous materials at low pressures and temperatures. Chem Eng $J$ 2016, 302:278-286. http://dx.doi.org/10.1016/j.cej.2016.05.057. 

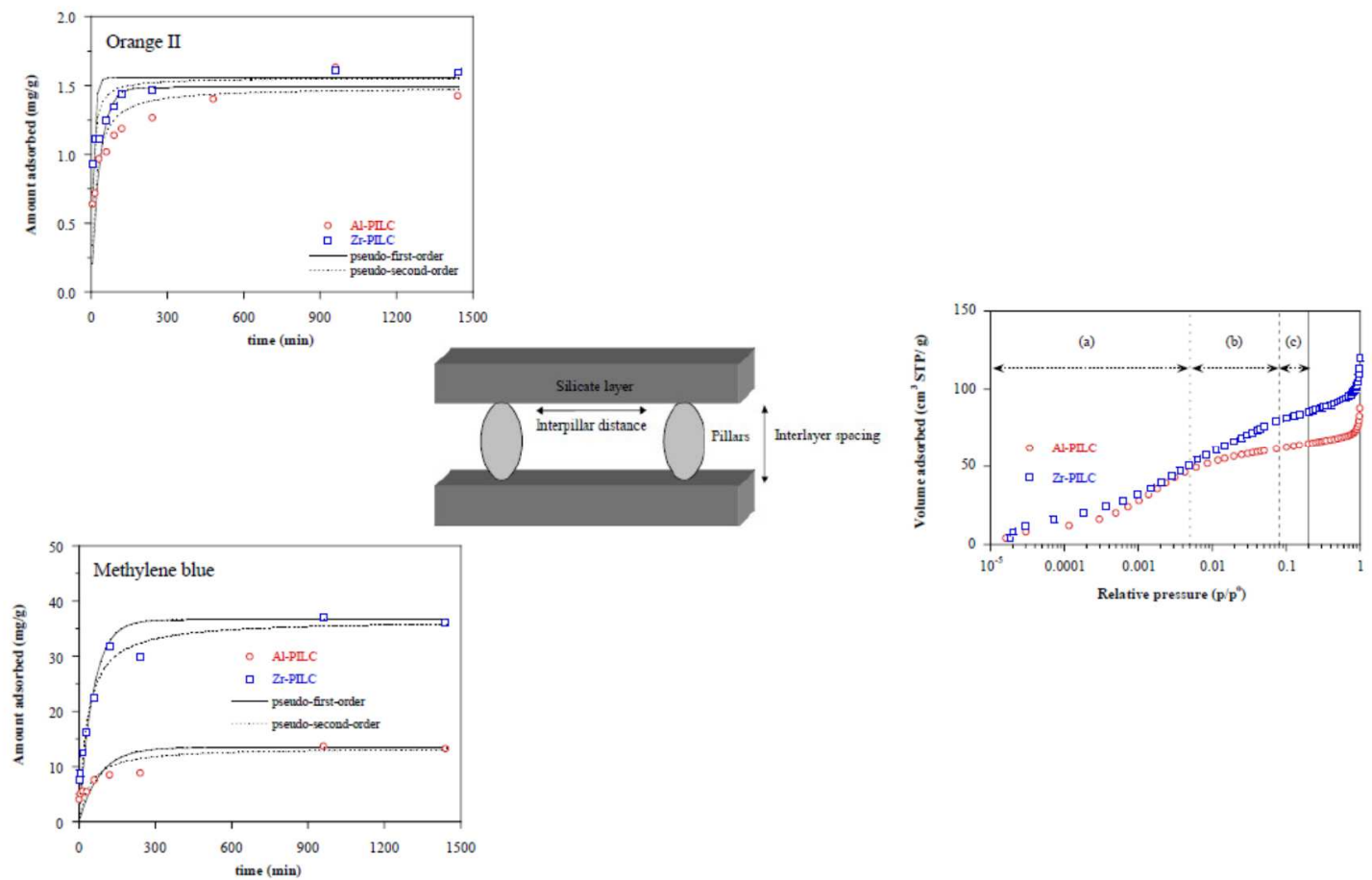

Figure 1. Adsorption selective of Orange II and Methylene Blue on Al- and Zr-PILCs explained by the porous properties of the materials. Characterization textural by adsorption of $\mathrm{N} 2$ at $77 \mathrm{~K}$ of PILCs: (a) ultramicropore, (b) micropore and (c) supermicropore region. (Adapted from [4]). 


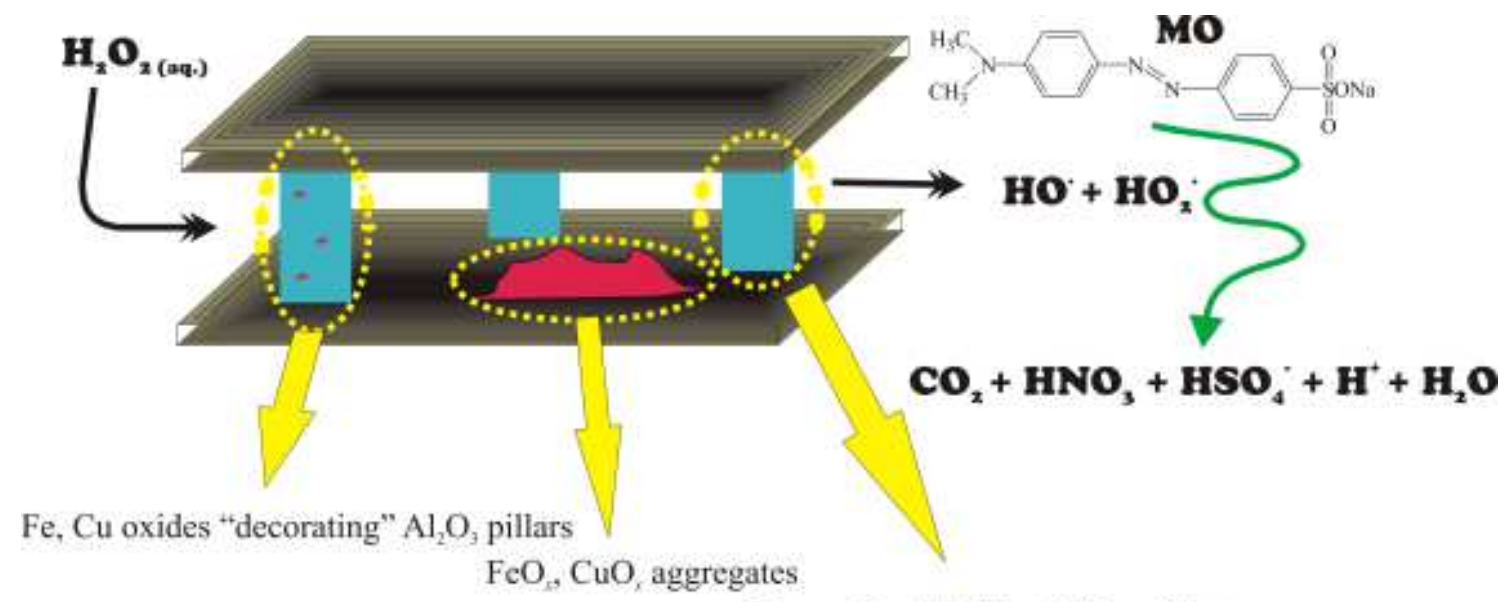

True mixed $\mathrm{Al} / \mathrm{Fe}-, \mathrm{Al} / \mathrm{Cu}$ - pillars

Figure 2. Proposal of $\mathrm{Al} / \mathrm{Fe}-, \mathrm{Al} / \mathrm{Cu}-$ and $\mathrm{Al} /(\mathrm{Fe}-\mathrm{Cu})-\mathrm{PILCs}$ in the $\mathrm{CWPO}$ of methyl orange. (From [34]). 

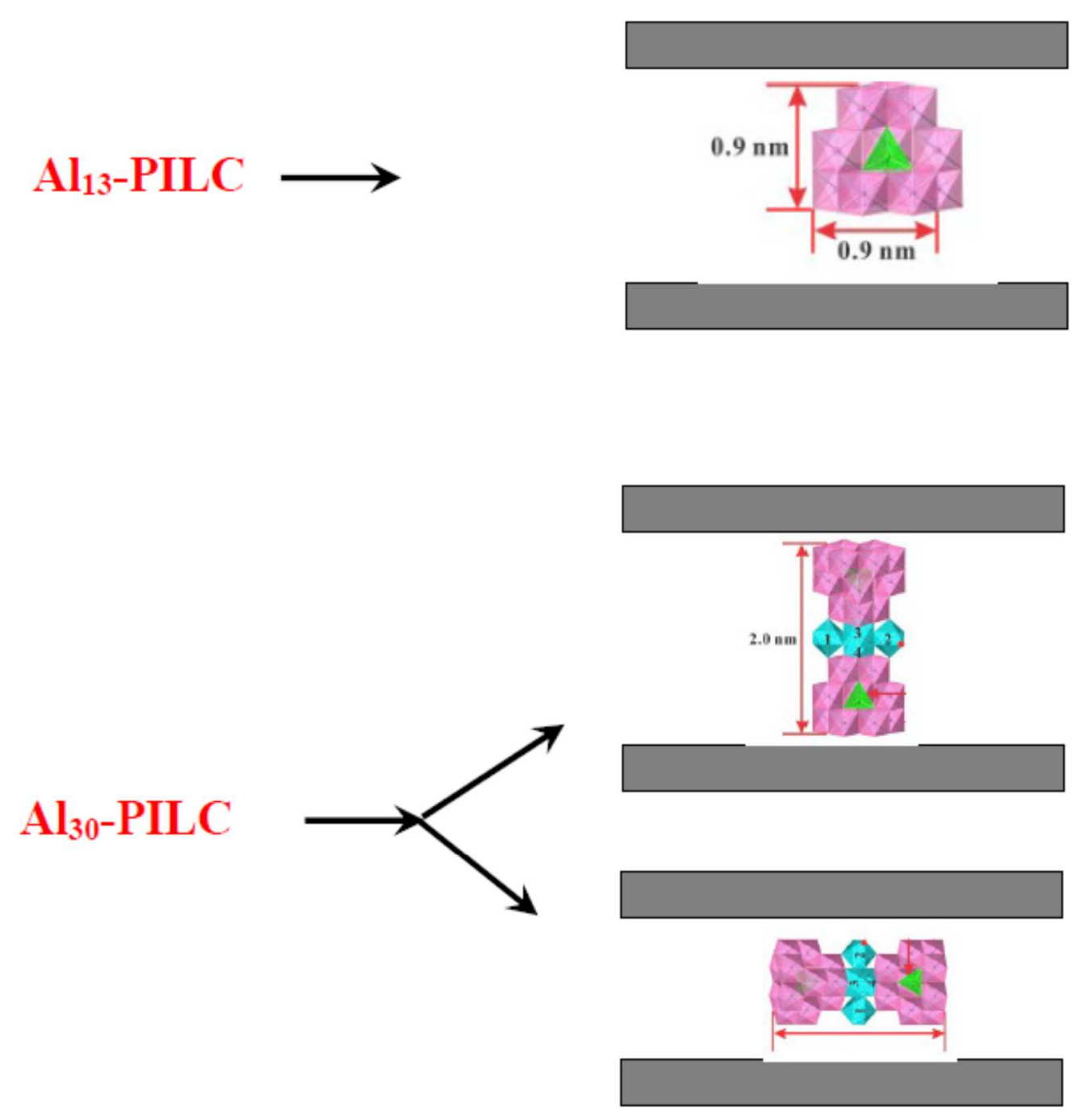

Figure 3. Structural comparison of $\mathrm{Al}_{13}-$ and $\mathrm{Al}_{30}-\mathrm{PILC}$ species. 

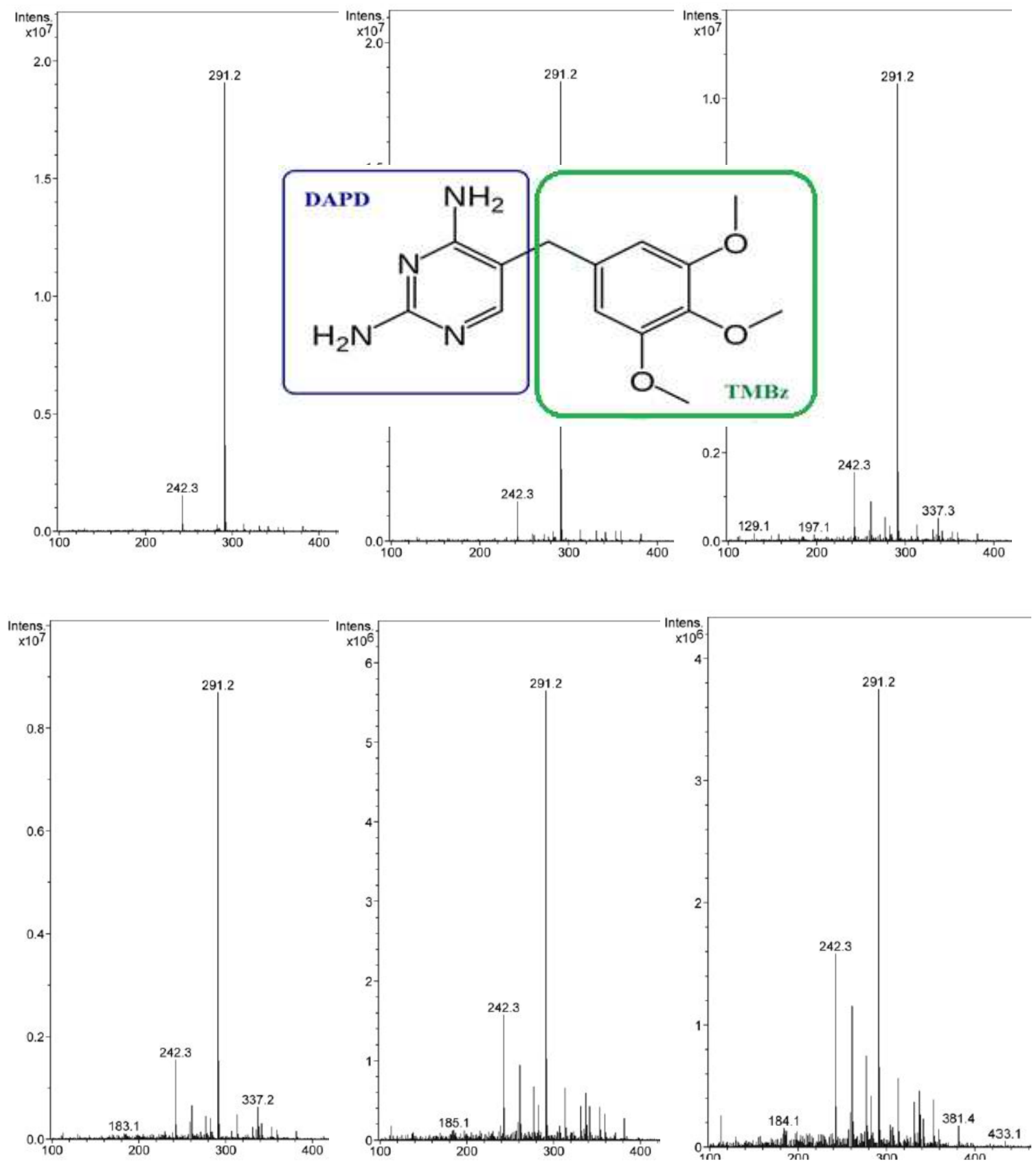

Figure 4. Mass spectra of the reaction solution after several degradation times using $\mathrm{Cr} / \mathrm{Ti}$-PILC as catalyst. From left to right, up: 5, 10 and 45 minutes; bottom 60, 120 and 150 minutes. Proposal of fragmentation of the molecular structure of TMP into two substructures. (Adapted from [42]). 